\title{
Assessment of microbiological air quality in hemato-oncology units and its relationship with the occurrence of invasive fungal infections: an integrative review
}

\author{
Mayra Gonçalves Menegueti ${ }^{[1]}$, Lécio Rodrigues Ferreira ${ }^{[1]}$, Magda Fabbri Isaac Silva ${ }^{[1]}$, \\ Anderson Soares da Silva ${ }^{[1]}$ and Fernando Bellissimo-Rodrigues ${ }^{[1],[2]}$
}

[1]. Comissão de Controle de Infecção Hospitalar, Hospital das Clínicas, Faculdade de Medicina de Ribeirão Preto, Universidade de São Paulo, Ribeirão Preto, SP. [2]. Departamento de Medicina Social, Faculdade de Medicina de Ribeirão Preto, Universidade de São Paulo, Ribeirão Preto, SP.

\begin{abstract}
Worldwide aging of the human population has promoted an increase in the incidence of neoplasia, including hematological cancers, which render patients particularly vulnerable to invasive fungal infections. For this reason, air filtration in hematooncology units has been recommended. However, scarce literature has assessed the impact of microbiological air quality on the occurrence of fungal infections in this population. We performed an integrative review of studies in the MEDLINE database that were published between January 1980 and October 2012, using the following combinations of keywords: air $\times$ quality $\times$ HEPA, air $\times$ quality $\times$ hematology, and airborne fungal infections. The search yielded only 13 articles, suggesting that high-efficiency filtering of the ambient air in hemato-oncology units can prevent the incidence of invasive fungal infections. However, no randomized clinical trial was found to confirm this suggestion. Currently, there is no consensus about the maximum allowable count of fungi in the air, which complicates filtration monitoring, including filter maintenance and replacement, and needs to be addressed in future studies.
\end{abstract}

Keywords: Airborne fungal infections. Invasive aspergillosis. High-efficiency particulate air filter. Hematology. Bone marrow transplantation.

\section{INTRODUCTION}

The expansion of the elderly population is a worldwide phenomenon that is also occurring in Brazil, and with this expansion comes an increased incidence of neoplasia ${ }^{1}$. Cancer is now a major public health problem in Brazil and many other parts of the world. It is estimated that in this country, 1 in 3 women and 1 in 2 men will develop cancer during their lifetime ${ }^{2}$.

Medullary neoplasias, particularly acute myeloid leukemia, are rarely diagnosed before age 40 but exhibit an exponential increase in incidence with age. The molecular and cellular mechanisms associated with this age-related increase remain poorly understood ${ }^{3}$. Hematopoietic stem cell transplantation has been a widely used alternative in the treatment of leukemias ${ }^{4}$. However, it is important to note that both the period of neutropenia prior to the grafting of these cells and chemotherapy-induced neutropenia involve intense immunosuppression of these patients, making these individuals

Address to: Dr. Fernando Bellissimo-Rodrigues. Dept ${ }^{\circ}$ de Medicina Social/HC/ FMRP/USP. Av. Bandeirantes 3900/2 ${ }^{\circ}$ andar, Bairro Monte Alegre, 14049-900 Ribeirão Preto, SP, Brasil.

Phone: 5516 3602-2714; Fax: 5516 3602-1562

e-mail: fbellissimo@fmrp.usp.br

Received 1 February 2013

Accepted 25 May 2013 susceptible to various infections that affect treatment outcomes ${ }^{5}$. Invasive fungal infections, particularly aspergillosis, are common in these patients and have high morbidity and mortality rates in immunocompromised patients ${ }^{6}$.

In this context, the microbiological air quality in oncological units is important, particularly in the prevention of fungal infections. The Centers for Disease Control and Prevention recommends air filtration using high-efficiency particulate air (HEPA) filters? ${ }^{7}$ The Spanish Society of Infectious Diseases and Clinical Microbiology (SEIMC) ${ }^{8}$ also recommends that places designated as a protective environment be separated from the rest of the hospital and have a heating, ventilation, and air conditioning system with a HEPA filter that completes at least 12 full exchanges of air per hour ${ }^{8}$.

The minimum acceptable limits for fungal growth in these units remain controversial. The SEIMC sets a limit of 0.5 $\mathrm{CFU} / \mathrm{m}^{3}$ in the air of protective environment areas. This limit entails the detection of no more than one colony of filamentous fungi within a $2-\mathrm{m}^{3}$ sample of air. This recommendation is justified by evidence that concentrations as low as $1 \mathrm{CFU} / \mathrm{m}^{3}$ can cause infection in high-risk patients. However, it has also been suggested that studies be conducted at individual centers to first determine the normal concentrations and then detect significant increases ${ }^{8}$.

Given that this topic is scarcely discussed and controversial in the literature and that there is no consensus on the safety limits 
for air filtration, this study aimed to review the literature on air quality and its association with fungal infections in hematooncology patients.

\section{GENERAL OBJECTIVE}

To review the literature on air quality and its association with fungal infections in hemato-oncology patients.

\section{SPECIFIC OBJECTIVES}

1) To identify the impact of air filtration on the incidence of invasive aspergillosis in patients with hemato-oncological cancers during restructuring periods. 2) To identify the impact of air filtration on the routine incidence of invasive aspergillosis in patients with hemato-oncological cancers outside of restructuring periods. 3) To identify the maximum fungal concentration in HEPA-filtered air above which there would be a correlation between the fungal concentration and an increased incidence of aspergillosis.

\section{METHODS}

This study is an integrative review of the literature, which is an approach that can make research results more accessible, reduce certain barriers to the use of scientific knowledge, and enable a reader to gain access to various surveys conducted in a single study ${ }^{9}$. The main question in this integrative review was What scientific knowledge is there regarding air quality and its association with fungal infections in hemato-oncology patients?

This survey was conducted using the MEDLINE database and the following combinations of keywords: air $\times$ quality $\times$ HEPA, air $\times$ quality $\times$ hematology, and airborne fungal infections. The inclusion criteria established in this selection were the availability of full-text articles published between January 1990 and October 2012 in English or Portuguese that were primary studies focused on air quality and its association with fungal infections in adult hemato-oncology patients. Articles that discussed air filtration in operating rooms, patients with cystic fibrosis or asthma, or air quality in kindergartens and homes were excluded.

To collect the data, we used an instrument that allowed: 1) the identification of publications (title of the article and journal, main author, year of publication, and study sites); 2) the characterization of publications regarding the evaluation criteria in the studies (type of filter used); and 3) the characterization of methodological characteristics (type of study, study objectives, results, limitations, and conclusions).

\section{RESULTS AND DISCUSSION}

The final sample consisted of 13 articles. Figure 1 describes the inclusion process, as recommended by the PRISMA flowchart ${ }^{10}$.

Regarding the characterization of the studies' year of publication, Figure 2 shows that the studies were first published in 1998; since 2009, no further studies have been published on this topic. We also observed that the distribution was homogeneous in the number of articles published, and no single year was divergent.

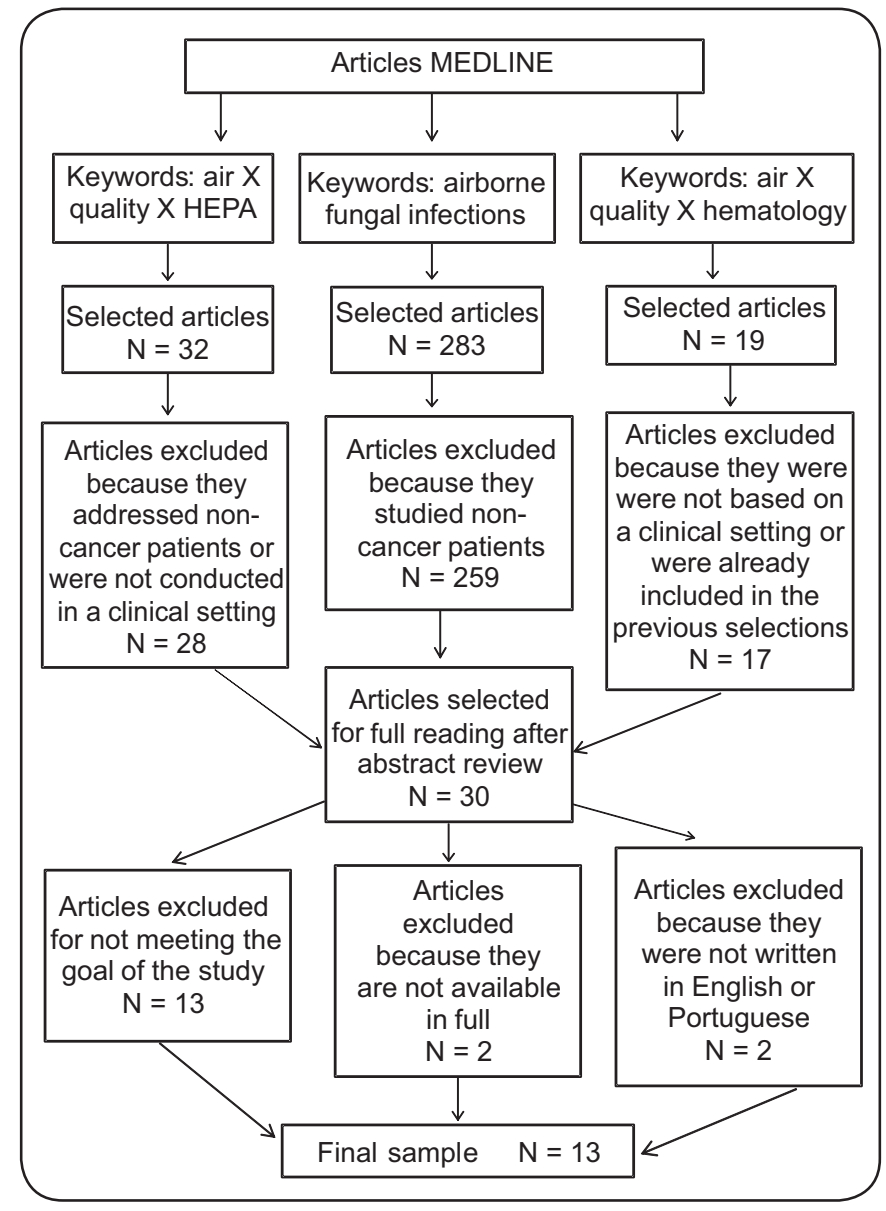

FIGURE 1 - Inclusion process for articles in the review. HEPA: high-efficiency particulate air.

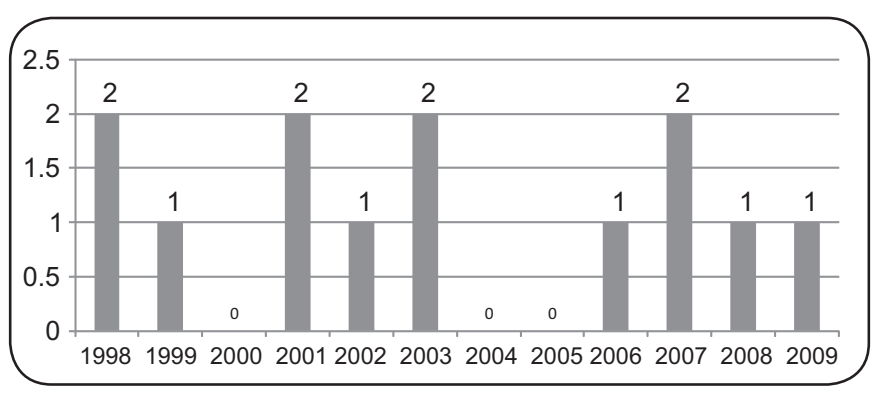

FIGURE 2 - Number of included articles in the review according to the year of publication.

An analysis of the articles enabled grouping according to the following subthemes: 1) effectiveness of HEPA filters in preventing invasive fungal infections in hemato-oncology patients during non-restructuring periods; 2) effectiveness of HEPA filters in preventing invasive fungal infections in hematooncology patients during restructuring periods; and 3) efficacy of HEPA filters in reducing the fungal concentration in the air in hemato-oncology units, without addressing patient outcomes.

Effectiveness of HEPA filters in preventing invasive fungal infections in hemato-oncology patients during non-restructuring periods: This subtheme included six studies ${ }^{11-16}$, five $\mathrm{e}^{11-15}$ of which 
showed a benefit for air filtration via reduced $\mathrm{CFU}$ values and a subsequent reduction in the number of fungal infections and/ or decreased patient mortality after transplantation. However, Hospenthal et al. ${ }^{16}$ questioned the impact of HEPA filters on the prevention of invasive aspergillosis. Table 1 presents the core findings of these studies.

Effectiveness of HEPA filters in preventing invasive fungal infections in hemato-oncology patients during restructuring periods:

TABLE 1 - Results of studies evaluating the effectiveness of HEPA filters in preventing invasive fungal infections in hemato-oncology patients during non-restructuring periods.

\begin{tabular}{|c|c|c|c|c|}
\hline Authors and year & Study population & Methods & Core results & Conclusions \\
\hline Araújo et al., $2008^{11}$ & $\begin{array}{l}221 \text { hemato- } \\
\text { oncology patients }\end{array}$ & $\begin{array}{l}\text { Quasi-experimental study } \\
\text { (before and after HEPA } \\
\text { filter implementation) }\end{array}$ & $\begin{array}{l}\text { Air fungal counts (from } 22- \\
278 \text { to } 7 \mathrm{CFU} / \mathrm{m}^{3} \text { ) and fungal } \\
\text { infections (from } 6.6 \% \text { to } \\
4.9 \% \text { ) decreased after } \\
\text { renovation and HEPA filter } \\
\text { installation }\end{array}$ & $\begin{array}{l}\text { HEPA filters were } \\
\text { effective in reducing both } \\
\text { the fungal concentration } \\
\text { in the air and the } \\
\text { incidence of fungal } \\
\text { infections }\end{array}$ \\
\hline Bénet et al., $2007^{12}$ & $\begin{array}{l}356 \text { intensive-care } \\
\text { hemato-oncology } \\
\text { patients }\end{array}$ & $\begin{array}{l}\text { Quasi-experimental study } \\
\text { (before and after HEPA } \\
\text { filter implementation) }\end{array}$ & $\begin{array}{l}\text { Invasive aspergillosis } \\
\text { incidence decreased from } \\
13.2 \% \text { to } 1.6 \% \text { after HEPA } \\
\text { filter installation }\end{array}$ & $\begin{array}{l}\text { HEPA filters were } \\
\text { effective in reducing the } \\
\text { incidence of fungal } \\
\text { infections }\end{array}$ \\
\hline Hahn et al., $2002^{13}$ & $\begin{array}{l}91 \text { hemato-oncology } \\
\text { patients with a } \\
\text { baseline low risk of } \\
\text { fungal infection }\end{array}$ & $\begin{array}{l}\text { Outbreak investigation } \\
\text { with a quasi- } \\
\text { experimental intervention } \\
\text { (before and after HEPA } \\
\text { filter implementation) }\end{array}$ & $\begin{array}{l}\text { During the outbreak, the } \\
\text { Aspergillus air count was } \\
>150 \mathrm{CFU} / \mathrm{m}^{3} \text {. After HEPA } \\
\text { filter installation, the count } \\
\text { decreased to }<4 \mathrm{CFU} / \mathrm{m}^{3} \text {, } \\
\text { which controlled the outbreak }\end{array}$ & $\begin{array}{l}\text { HEPA filters were } \\
\text { effective in reducing both } \\
\text { the fungal concentration } \\
\text { in the air and the } \\
\text { incidence of fungal } \\
\text { infections }\end{array}$ \\
\hline Alberti et al., $2001^{14}$ & $\begin{array}{l}\text { Bone marrow } \\
\text { transplantation unit } \\
\text { and two } \\
\text { hematology wards }\end{array}$ & $\begin{array}{l}\text { Retrospective cohort } \\
\text { study comparing rooms } \\
\text { with HEPA filters with } \\
\text { rooms with conventional } \\
\text { filters (less effective than } \\
\text { HEPA filters) }\end{array}$ & $\begin{array}{l}\text { Of all air samples, } 1.1 \% \text { were } \\
\text { positive for Aspergillus spp. } \\
\text { in rooms equipped with } \\
\text { HEPA filters, whereas } 6.7- \\
9.4 \% \text { were positive in rooms } \\
\text { with conventional filters. The } \\
\text { authors detected a correlation } \\
\text { between air contamination } \\
\text { and invasive aspergillosis }\end{array}$ & $\begin{array}{l}\text { HEPA filters were } \\
\text { effective in reducing the } \\
\text { fungal concentration in } \\
\text { the air, which was } \\
\text { correlated with a } \\
\text { reduction in the incidence } \\
\text { of invasive aspergillosis }\end{array}$ \\
\hline Hospenthal et al., $1998^{16}$ & $\begin{array}{l}\text { Oncology unit with } \\
\text { HEPA filters }\end{array}$ & $\begin{array}{l}\text { Prospective cohort study } \\
\text { analyzing the incidence } \\
\text { of invasive fungal } \\
\text { infections among rooms } \\
\text { with variable } \\
\text { concentrations of conidia }\end{array}$ & $\begin{array}{l}\text { The average fungal } \\
\text { concentration was } 1.8 \\
\mathrm{CFU} / \mathrm{m}^{3} \text { for Aspergillus spp., } \\
\text { but individual samples reached } \\
\text { concentrations as high as } \\
11.6 \mathrm{CFU} / \mathrm{m}^{3} \text {. There were six } \\
\text { cases of invasive aspergillosis } \\
\text { during the study period }\end{array}$ & $\begin{array}{l}\text { There was no association } \\
\text { between the } \\
\text { concentration of conidia } \\
\text { and cases of invasive } \\
\text { aspergillosis }\end{array}$ \\
\hline
\end{tabular}


This theme included three studies ${ }^{17-19}$ demonstrating that HEPAfilters effectively reduced the fungal concentration in the air, thus possibly preventing cases of invasive fungal infections during restructuring periods. Table 2 presents the main findings of these studies.

Efficacy of HEPA filters in reducing the fungal concentration in the air in hemato-oncology units, without addressing patient outcomes: This theme included four studies ${ }^{20-23}$ that evaluated the efficacy of HEPA filters in reducing the fungal concentration in the air in hemato-oncology units but did not address patient outcomes. Two of the studies found that HEPA filter performance was no better than regular air filtration ${ }^{20,21}$. Another study found that HEPA filters effectively reduced the fungal concentration in the air but that water systems could be a source of Aspergillus spp., which are not completely eliminated by air filtration ${ }^{22}$. Finally, Cornet et al. ${ }^{23}$ reported that HEPA filters did not effectively prevent air contamination by fungi during a construction period, unless combined with laminar airflow $^{23}$. Table 3 presents the core findings of these studies.

\section{CONCLUSIONS}

Scientific observations evaluating the microbiological air quality in hemato-oncology units and the relationship between air quality and the incidence of invasive fungal infections in patients admitted to these units are relatively scarce. Compounding this lack of data, we found no randomized controlled trials evaluating the effectiveness of the cited preventive measures, which was likely due to the serious ethical restrictions associated with such trials.

Taken together, the available studies suggest that there is a certain clinical benefit associated with the treatment of ambient air in hemato-oncology units using HEPA filters and positive pressure. However, the studies were subject to selection bias because most of the studies analyzed non-randomized patients,

TABLE 2 - Results of studies evaluating the effectiveness of HEPA filters in preventing invasive fungal infections in hemato-oncology patients during restructuring periods.

\begin{tabular}{|c|c|c|c|c|}
\hline Authors and year & Study population & Methods & Main results & Conclusions \\
\hline Kruger et al., $2003^{18}$ & $\begin{array}{l}28 \text { patients } \\
\text { treated during } \\
\text { construction } \\
\text { and } 652 \text { patients } \\
\text { treated outside } \\
\text { of the } \\
\text { construction } \\
\text { period in a } \\
\text { HEPA filter- } \\
\text { equipped ward }\end{array}$ & $\begin{array}{l}\text { Quasi- } \\
\text { experimental } \\
\text { design analyzing } \\
\text { air contamination } \\
\text { and the incidence } \\
\text { of fungal } \\
\text { infections before, } \\
\text { during, and after } \\
\text { a period of } \\
\text { construction }\end{array}$ & $\begin{array}{l}\text { Air samples yielded Aspergillus at a } \\
\text { concentration of } 0-2 \mathrm{CFU} / \mathrm{m}^{3} \text { before } \\
\text { construction, } 0-5 \mathrm{CFU} / \mathrm{m}^{3} \text { during } \\
\text { construction, and } 0 \mathrm{CFU} / \mathrm{m}^{3} \text { after } \\
\text { construction. The incidence of invasive } \\
\text { aspergillosis was similar between the } \\
\text { three periods }\end{array}$ & $\begin{array}{l}\text { HEPA filters provided } \\
\text { effective protection } \\
\text { against invasive } \\
\text { aspergillosis, despite } \\
\text { construction }\end{array}$ \\
\hline Oren et al., $2001^{19}$ & $\begin{array}{l}111 \text { high-risk } \\
\text { patients treated } \\
\text { before and after } \\
\text { HEPA filter } \\
\text { installation }\end{array}$ & $\begin{array}{l}\text { Outbreak } \\
\text { investigation } \\
\text { during a } \\
\text { construction } \\
\text { period, with a } \\
\text { quasi- } \\
\text { experimental } \\
\text { intervention }\end{array}$ & $\begin{array}{l}\text { The average air concentration of Aspergillus } \\
\text { was } 15 \mathrm{CFU} / \mathrm{m}^{3} \text { in the non-filtered period } \\
\text { and } 0.18 \mathrm{CFU} / \mathrm{m}^{3} \text { in the filtered period. The } \\
\text { incidence of invasive aspergillosis was } 50 \% \\
\text { before HEPA filters and chemoprophylaxis, } \\
43 \% \text { after amphotericin B prophylaxis, and } \\
0 \% \text { after HEPA filter implementation and } \\
\text { continuing chemoprophylaxis }\end{array}$ & $\begin{array}{l}\text { In a construction period, } \\
\text { HEPA filters were } \\
\text { more effective than } \\
\text { amphotericin B in } \\
\text { protecting patients } \\
\text { against invasive } \\
\text { aspergillosis. }\end{array}$ \\
\hline
\end{tabular}

HEPA: high-efficiency particulate air; $\mathrm{CFU} / \mathrm{m}^{3}$ : colony-forming units per cubic meter. 
TABLE 3 - Results of studies evaluating air filtration and performing a mycological analysis of the air in hemato-oncology units, without analyzing patients.

\begin{tabular}{|c|c|c|c|c|}
\hline Authors and year & Study population & Methods & Main results & Conclusions \\
\hline Crimi et al., $2009^{20}$ & $\begin{array}{l}\text { Two hematology } \\
\text { units, only one of } \\
\text { which was equipped } \\
\text { with HEPA filters }\end{array}$ & $\begin{array}{l}\text { Cross-sectional study } \\
\text { addressing air } \\
\text { contamination and its } \\
\text { relationship with air } \\
\text { filtration }\end{array}$ & $\begin{array}{l}\text { No fungi were found in air } \\
\text { samples, but bacteria were } \\
\text { isolated from the air samples } \\
\text { from the non-filtered unit }\end{array}$ & $\begin{array}{l}\text { Both units performed } \\
\text { equivalently regarding air } \\
\text { contamination by fungi. }\end{array}$ \\
\hline Cornet $1999^{23}$ & $\begin{array}{l}\text { Three hematology } \\
\text { units equipped with } \\
\text { HEPA filters alone } \\
\text { (unit A1) or with } \\
\text { HEPA filters and } \\
\text { laminar airflow (unit } \\
\text { A2) or a non-filtered } \\
\text { area (unit B) }\end{array}$ & $\begin{array}{l}\text { Prospective cohort study } \\
\text { analyzing the } \\
\text { concentration of fungi } \\
\text { prior to, during, and after } \\
\text { a period of construction } \\
\text { in the three units }\end{array}$ & $\begin{array}{l}\text { Overall, a major increase in } \\
\text { fungal concentration was } \\
\text { detected in air samples } \\
\text { collected during a } \\
\text { construction period from } \\
\text { units A1 and B, but not from } \\
\text { unit A2, which had no air } \\
\text { cultures that were positive } \\
\text { for Aspergillus spp. Fungal } \\
\text { infections were not assessed }\end{array}$ & $\begin{array}{l}\text { HEPA filters alone were } \\
\text { not effective in } \\
\text { preventing air } \\
\text { contamination by fungi } \\
\text { during a construction } \\
\text { period but were effective } \\
\text { when combined with } \\
\text { laminar airflow }\end{array}$ \\
\hline
\end{tabular}

HEPA: high-efficiency particulate air; $\mathrm{CFU} / \mathrm{m}^{3}$ : colony-forming units per cubic meter.

and several of the investigations were performed in specific restructuring situations. Moreover, invasive fungal infection is an outcome related to many other risk factors, including the following: the degree of immunosuppression induced by either a hematologic disease and/or its treatment; comorbidities, including previous pulmonary diseases; the use of anti-fungal prophylaxis; and the microbiological quality of the tap water in the units. Thus, from a scientific perspective, one cannot be sure that the benefits observed in the cited studies were strictly related to air filtration.

It is important to highlight that HEPA filter installation alone is likely insufficient to guard against infection; proper maintenance must also be performed. If any preventive benefit is actually associated with the use of this type of system, this benefit will likely occur only when the equipment is operated according to the manufacturer's recommendations, using unsaturated filters. Larger doubts remain regarding the maximum allowable count of fungi in the air because levels vary widely between studies. This lack of consensus makes it difficult to estimate a cutoff above which we can establish a direct association with the incidence of fungal infections. We believe that this issue should be addressed by future studies. 


\section{CONFLICT OF INTEREST}

The authors declare that there is no conflict of interest.

\section{FINANCIAL SUPPORT}

The present study was partially supported by Fundação de Apoio ao Ensino, Pesquisa e Assistência (FAEPA) do Hospital das Clínicas da Faculdade de Medicina de Ribeirão Preto da Universidade de São Paulo, a non-profit organization.

\section{REFERENCES}

1. Veras R. Population aging today: demands, challenges and innovations. Rev Saude Publica 2009;43:548-554.

2. Siegel R, DeSantis C, Virgo K, Stein K, Mariotto A, Smith T, et al. Cancer Treatment and Survivorship Statistics. Ca Cancer J Clin 2012; 62:220-241.

3. Warner JK, Wang JCY, Hope KJ, Jin L, Dick JE. Concepts of human leukemic development. Oncogene 2004; 23:7164-7177.

4. Devine H, Demeyer E. Hematopoietic cell transplantation in the treatment of leukemia. Semin Oncol Nurs 2003; 19:118-132.

5. Garbin LM, Silveira RCCP, Braga FTM, Carvalho EC. Measures used to prevent infections in transplanted hematopoietic stem cells: evidence for practice. Rev Latinoam Enferm 2011; 19:640-650.

6. Steinbach WJ, Marr KA, Anaissie EJ, Azie N, Quan SP, Meier-Kriesche $\mathrm{HU}$, et al. Clinical epidemiology of 960 patients with invasive aspergillosis from the PATH Alliance registry. J Infect 2012; 65:453-464.

7. Centers for Disease Control and Prevention (CDC). Guidelines for preventing opportunistic infections among hematopoietic stem cell transplant recipients. MMWR Recomm Rep 2000; 49:1-125.

8. Ruiz-Camps I, Aguado JM, Almirante B, Bouza E, Ferrer-Barbera CF, Len $\mathrm{O}$, et al. Guidelines for prevention of invasive mould diseases caused by filamentous fungi by Spanish Society of Infectious Diseases and Clinical Microbiology (SEIMC). Clin Microbiol Infect 2011; 17 (suppl 2):1-24.

9. Ganong LH. Integrative Reviews of Nursing Research. Research in Nursing \& Health 1987; 10:1-11.

10. PRISMA flowchart [internet]. Transparent reparting of systematic reviews and meta-analyses. Available online at: http://www.prismastatement.org/ statement.htm. [cited 2012 December 18].

11. Araújo R, Carneiro A, Oliveira SC, Vaz CP, Rodrigues AG, Guimaraes JE. Fungal infections after haematology unit renovation: evidence of clinical, environmental and economical impact. Eur J Haematol 2008; 80:436-443.
12. Bénet T, Nicolle MC, Thiebaut A, Piens MA, Nicolini FE, Thomas $\mathrm{X}$, et al. Reduction of Invasive Aspergillosis Incidence among Immunocompromised Patients after Control of Environmental Exposure. Clin Infect Dis 2007; 45:682-686.

13. Hahn T, Cummings M, Michalek AM, Lipman BJ, Segal BH, McCarthy PL. Efficacy of High-Efficiency particulate air filtration in preventing Aspergillosis in immunocompromised patients with hematologic malignancies. Infect Control Hosp Epidemiol 2002; 23:525-531.

14. Alberti C, Bouakline A, Ribaud P, Lacroix C, Rousselot P, Leblanc T, et al. Aspergillus Study Group. Relationship between environmental fungal contamination and the incidence of invasive aspergillosis in haematology patients. J Hosp Infect 2001; 48:198-206.

15. Passweg JR, Rowlings PA, Atkinson KA, Barret AJ, Gale RP, Gratwohl A, et al. Influence of protective isolation on outcome of allogeneic bone marrow transplantation for leukemia. Bone Marrow Transplant 1998; 21:1231-1238.

16. Hospenthal DR, Kwon-Chung KJ, Bennett JE. Concentrations of airborne Aspergillus compared to the incidence of invasive aspergillosis: lack of correlation. Med Mycol 1998; 36:165-168.

17. Nihtinen A, Anttila VJ, Richardson M, Meri T, Volin L, Ruutu T. The utility of intensified environmental surveillance for pathogenic moulds in a stem cell transplantation ward during construction work to monitor the efficacy of HEPA filtration. Bone Marrow Transplant 2007; 40:457-460.

18. Kruger WH, Zollner B, Kaulfers PM, Zander AR. Effective protection of allogeneic stem cell recipients against Aspergillosis by HEPA air filtration during a period of construction a prospective survey. J Hematother Stem Cell Res 2003; 12:301-307.

19. Oren I, Haddad N, Finkelstein R, Rowe JM. Invasive pulmonary aspergillosis in neutropenic patients during hospital construction: before and after chemoprophylaxis and institution of HEPA filters. Am J Hematol 2001; 66:257-262.

20. Crimi P, Valgiusti M, Macrina G, Grieco A, Massone L, Ciucci A, et al. Evaluation of microbial contamination of air in two haematology departments equipped with ventilation systems with different filtration devices. J Prev Med Hyg 2009; 50:33-36.

21. Crimi P, Argellati F, Macrina G, Tinteri C, Copello L, Rebora D. Microbiological surveillance of hospital ventilation systems in departments at high risk of nosocomial infections. J Prev Med Hyg 2006; 47:105-109.

22. Anaissie EJ, Stratton SL, Dignani MC, Lee CK, Summerbell RC, Rex JH. Pathogenic molds (including Aspergillus species) in hospital water distribution systems: a 3-year prospective study and clinical implications for patients with hematologic malignancies. Blood 2003; 101:2542-2546.

23. Cornet M, Levy V, Fleury L, Lortholary J, Barquins S, Coureul $\mathrm{MH}$, et al. Efficacy of prevention by high-efficiency particulate air filtration or laminar airflow against Aspergillus airborne contamination during hospital renovation. Infect Control Hosp Epidemiol 1999; 20: 508-513. 